\title{
Trace Elements Have Beneficial, as Well as Detrimental Effects on Bone Homeostasis
}

\author{
I. ZOFKOVA ${ }^{1}$, M. DAVIS ${ }^{2}$, J. BLAHOS ${ }^{3}$ \\ ${ }^{1}$ Institute of Endocrinology, Prague, Czech Republic, ${ }^{2}$ Ecologia Environment, Perth, Australia, \\ ${ }^{3}$ Osteocentrum, Central Military Hospital, Prague, Czech Republic
}

Received July 31, 2016

Accepted October 27, 2016

On-line February 28, 2017

\section{Summary}

The protective role of nutrition factors such as calcium, vitamin D and vitamin $\mathrm{K}$ for the integrity of the skeleton is well understood. In addition, integrity of the skeleton is positively influenced by certain trace elements (e.g. zinc, copper, manganese, magnesium, iron, selenium, boron and fluoride) and negatively by others (lead, cadmium, cobalt). Deficiency or excess of these elements influence bone mass and bone quality in adulthood as well as in childhood and adolescence. However, some protective elements may become toxic under certain conditions, depending on dosage (serum concentration), duration of treatment and interactions among individual elements. We review the beneficial and toxic effects of key elements on bone homeostasis.
\end{abstract}

\section{Key words}

Bone mineral density $\bullet$ Bone quality $\bullet$ Boron $\bullet$ Cadmium $\bullet$ Copper - Iron • Fluoride • Lead • Magnesium • Manganese • Selenium • Zinc

\section{Corresponding author}

I. Zofkova, Institute of Endocrinology, Narodni 8, 11694 Prague 1, Czech Republic. E-mail: izofkova@upcmail.cz

\section{Introduction}

Bone metabolism is defined by the interaction between osteoclasts, which determine bone resorption, and osteoblasts, which ensure bone formation. Predominance of osteoclastic activity evoked by endocrine, systemic diseases, as well as nutrition state, accelerates bone loss and increases fracture risk. Further key cell activating bone formation is osteocyte, working first of all via mechanoreceptors.

The importance of trace elements in bone regulation is well established. Whereas copper, boron, zinc, selenium, manganese, or magnesium have osteo-protective effects, cadmium, cobalt and lead are toxic. However, the effect of high concentrations of certain bone protective elements (e.g. fluoride) is questionable. A deficit of protective elements, most frequently due to low intake in food, as well as high exposure to toxic elements (e.g. in highly industrial areas) can lead to serious diseases including osteoporosis. This review summarizes contemporary knowledge concerning the positive and/or detrimental effects of trace elements on bone homeostasis. Trace elements are listed in alphabetical order in respective chapter.

\section{Trace elements with prevailing positive effect on the skeleton}

Boron

Boron stabilizes cell membranes and modulates membrane transport mechanisms. It has anti-inflammatory, antineoplastic and hypolipidemic effects. It also stimulates bone growth and bone metabolism (Hunt 2012). Boron activates $1,25(\mathrm{OH})_{2} \mathrm{D}_{3}$ production and thus increases bone mineralization (Hakki et al. 2013). Adequate boron intake is beneficial for trabecular bone microarchitecture and cortical bone strength (Nielsen and Stoecker 2009). Boron is ubiquitously present in water, soil and plants (the latter 
including vegetables, fruits and nuts). It is well tolerated when administered orally and measurable in all tissues. Daily boron intake in adults is usually around 1-2 mg/day. The recommended daily dose to support good bone health is $3 \mathrm{mg}$ (reviewed by Zofkova et al. 2013).

\section{Copper}

Copper is a general catalytic cofactor, which, both in oxidized and reduced form, affects the redox state in the body. Its deficiency can result in impaired glucose and cholesterol metabolism, energy production, blood and immune cells and altered myocardial contractility (Hordyjewska et al. 2014). Copper deficiency leads to idiopathic myelopathy in adults (Kumar et al. 2004, Page et al. 2015) or progressive peripheral neuropathy (Coyle et al. 2015). On the other hand, increased copper levels have been detected in relation to some diseases, such as Menke's disease and Wilson's disease and have some role in formation of plaques in Alzheimer's disease (Brewer 2003).

Copper plays an important role in regulation of bone growth and development of the skeleton. The element induces the formation of lysine crosslinks in collagen and elastin via lysyl oxidase activation. As a cofactor of antioxidant enzymes, it removes bone free radicals that cause the osteoclast activation (Kubiak et al. 2010). In addition, copper inhibits osteoclastic bone resorption directly ( $\mathrm{Li}$ and $\mathrm{Yu}$ 2007). Altogether, copper increases bone strength and helps to maintain the optimal state of bone quality.

In premature infants between 5 and 6 months of age, copper deficiency was linked to radiographic findings of metabolic bone disease, including osteoporosis, metaphyseal changes, and physeal disruptions (Marquardt et al. 2012). In consensus with the later observation, is a study performed on osteoporotic post-menopausal women, who had significantly lower serum copper as compared to controls (Midhavi-Roshan et al. 2015). Importance of copper in bone regulation also supports the observation of low content of the element in enamel in adult patients with markedly reduced lumbar spine BMD accompanied by severe tooth wear. This phenomenon has been independent of serum 25(OH)D vitamin, PTH, or osteocalcin levels (Sierpinska et al. 2014).

In the elderly, physiological decline in the gastrointestinal absorption may induce copper deficiency. Thus, balanced copper homeostasis is undoubtedly of primary importance for skeletal growth during childhood, as well as for bone health in adult age.

The recommended daily intake of copper for adequate bone quality in adults is $0.9 \mathrm{mg}$ /day (Price et al. 2012). Additional clinical studies in larger groups are needed to find conclusive data.

\section{Fluoride}

The role of fluoride in the maintenance of bone health is full of controversy. Its positive effect is documented by some in vitro studies. Osteoblastic MG-63 cells culture, exposed to fluoride for one week, increased migration of these cells, promoted osteogenic cell differentiation and stimulated ALP concentration in the medium (Ohno et al. 2013). In rats, fluoride administration increased expression of mRNA of COL1A1, ALP and Runx2, which could be blocked by DKK-2, an inhibitor of the $\mathrm{Wnt} / \beta$-catenin receptor. Thus fluoride stimulates osteoblastogenesis by the canonical Wnt pathway (Pan et al. 2014). In vivo, the direct effect of fluoride on bone formation is intensified by overproduction of somatomedin. Nevertheless, fluoride treatment did not influence bone strength, although it increased bone mass (Turner et al. 1997). The clinical significance of fluoride"s bone anabolic effect in vivo was questioned, when no association was found between daily intake of fluoride and BMD at lumbar spine and at the hip in a group of adolescents (Levy et al. 2014). Similarly, low-dose fluoride had no effect on bone mass and bone metabolic turnover in a relatively large group of post-menopausal women with osteopenia (Grey et al. 2013). At excessive exposure levels, intake of fluoride causes skeletal (and dental) fluorosis together with manifestations of gastrointestinal and neurological complications (Jha et al. 2011). Some authors explain the detrimental effect of fluoride on the skeleton by an overproduction of parathormone and activated bone resorption (Puranic et al. 2015, Koroglu et al. 2011).

The sources of fluoride in the environment are fluorite, fluoroapatite and cryolite, as well as compounds of anthropogenic origin, such as coal burning or brick-making industries. Fluoride in food is soluble, $90 \%$ of it is absorbed in the gastrointestinal tract and sequestered mainly in bone and teeth (Jha et al. 2011). The variability of fluoride intake in heterogeneous populations is high, ranging from low to toxic values (Chachra et al. 2010). Exposure to fluoride could be quantified using urinary and serum fluoride, ALP, bALP and BGP, as demonstrated in animals (Song et al. 2011). 


\section{Iron}

As an enzymatic cofactor, iron stimulates synthesis of bone matrix via activation of lysyl hydroxylase. Iron also activates 25-hydroxycholecalciferol hydroxylase and supports mineralization of bone matrix through vitamin D. Rats suffering from a severe iron deficiency had poorly mineralized skeleton (Parelman et al. 2006) together with lower cortical width in femur and tibia, pathological changes in the microarchitecture of the vertebral trabecular bone and decreased bone strength (Madeiros et al. 2004). In addition, severe iron deficiency in rats was associated with a decline in biochemical markers of bone formation, such as procollagen type I N-terminal propeptide, which was normalized after a diet with adequate iron content (Diaz-Castro et al. 2012). Thus, iron appears to be a key nutrient necessary for integrity of the skeleton of adult animals. Besides, low iron status activates gene expression of FGF23, the molecule with a more common pathogenetic role in living organisms.

The bone-protective effect of iron has also been shown in a clinical study of patients with iron-deficiency anemia. Pre-menopausal women with non-recovered anemia had, after adjusting for age and BMI, significantly higher levels of bone resorption marker (NTx) and slightly lower bone formation marker (P1NP) compared to treated women (Wright et al. 2013). Therefore, bone resorption dominates over bone formation in pre-menopausal women with iron deficiency. However, osteopenia was also observed in patients with extremely high iron concentrations in tissues, e.g. due to genetically determined hemochromatosis (Guggenbuhl et al. 2005). In excess, ferric ion activates osteoclastic differentiation, most probably through activation of marrow-derived macrophages. Oxidative stress (e.g. induced by hypoestrinism) may play a supporting role in this process (Xiao et al. 2015). In summary, the protective or destructive effects of iron on bone are a matter of tissue concentration. This phenomenon was also observed in some other trace elements. An adequate intake of iron has not been established with respect to bone mineral density.

\section{Magnesium}

About $60 \%$ of total magnesium is stored in the skeleton. Magnesium is an integral part of the apatite crystals, from which it is released in the course of bone resorption. It is a cofactor of a number of enzymes that are important for energy (ATP synthesis), lipid, protein and nucleic acid, as well as calcium metabolism (reviewed by Castiglioni et al. 2013). Magnesium deficiency is associated with gastrointestinal or renal diseases, sickle cell anemia and diabetes and it is also known to impede long-term antineoplastic and diuretic treatment. Low magnesium level alters cardiac excitability and neuromuscular function. Magnesium deficiency is often found in alcoholics and patients with Alzheimer disease, and elderly people with hypertension and cerebrovascular accidents (Volpe 2013). Hypomagnesemia is often found in patients after kidney transplantation due to increased renal magnesium wasting. It can increase mortality in patients with cardiovascular disease and/or cause graft dysfunction and disturbance of immunity (van Laceke and van Biesen 2015).

In the skeleton, magnesium supports production of hydroxyapatite (Aina et al. 2013) and bone marrow stromal cells mineralization (Yoshizawa et al. 2014). Magnesium also supports $1,25(\mathrm{OH})_{2} \mathrm{D}$ vitamin synthesis. Thus, magnesium deficiency via hypocalcaemia elevates parathormone synthesis and subsequently osteoclast activity. A stimulated release of inflammatory cytokines, such as tumor necrosis factor alpha (TNF $\alpha)$ - and interleukin-1 (Rude et al. 2009), may also play a potential role in this process. On the other hand, osteoblastic number and activity declines during magnesium deficiency (Kanazawa et al. 2007). Altogether, the consequence of magnesium deficiency is accelerated bone loss, which, together with decline in bone formation, leads to decreased trabecular volume and alteration of bone microarchitecture in a way similar to osteomalacia.

Clinical studies indicate that sufficient magnesium intake increases bone density in young adults (Matias et al. 2012). The protective effect of high magnesium intake on bone quality was documented in healthy women, using ultrasound measurement of the calcaneus (BUA) (Kim et al. 2011). An extensive analysis by Hayhoe et al. (2015) in a large group of adult subjects of both genders showed that dietary magnesium and serum magnesium were positively associated with calcaneal bone ultrasound analysis in women and negatively associated with fracture risk in both women and men. Furthermore, magnesium supported facilitated postoperative healing in orthopedic patients, in whom degradable fixation magnesium devices were used (Chaya et al. 2015). Thus, magnesium appears to be an important element for development of peak bone mass, as well as for integrity of the adult skeleton (Nieves 2013). 
Nevertheless, some alarming data exist on negative effects of elevated serum magnesium on the skeleton. Hypermagnesemia (e.g. in chronic renal failure) disturbs calcium/magnesium ratio, which may lead to a defect in mineralization and osteoblast differentiation (Leidi et al. 2011). Warning results were also revealed by the Women's Health Initiative Study, where in a group of more than 89,000 postmenopausal women, subjects with the highest quintile of magnesium intake also had the highest incidence of wrist fractures. This phenomenon may be, in fact, caused by deterioration of bone quality in subjects exposed to high magnesium concentration.

Apart from nutrition, genetics is also likely to be responsible for magnesium balance. This hypothesis stems from results of some association studies. Runnels (2011) found association between magnesium status and polymorphism TRPM6 in humans. A meta-analysis of genome-wide association studies (GWAS) showed an association between serum magnesium levels and variants at six genomic loci: MUC1, ATP2B1, DCDC5, TRPM6, SHROOM3 and MDS1. In addition, some of these genes were also associated with bone mineral density (Meyer et al. 2010). These observations may provide some new insights into the role of endogenous magnesium in the regulation of bone mass.

Subclinical magnesium deficiency has been found in most populations of Europe and North America due to relatively low intake of micronutrients concentrated in green vegetables, nuts or grains. Besides, magnesium absorption also varies with other dietary elements, such as phosphate, which forms insoluble complexes with magnesium. The recommended daily intake of magnesium necessary for bone health in young people under 30 years of age is $400 \mathrm{mg}$, in older subjects it is $320 \mathrm{mg}$ and $420 \mathrm{mg}$ for females and males, respectively. In practice, magnesium supplementation is required in all subjects with low magnesium levels (Nieves 2013).

\section{Manganese}

Manganese is an essential trace element, which plays a role in lipid and carbohydrate metabolism. In the skeleton, manganese positively modulates RANKL/OPG ratio in the process of bone formation, determining thickness of trabecular bone area and increasing trabecular number (Liu et al. 2015). Local delivery of manganese chloride $\left(\mathrm{MnCl}_{2}\right)$ increased significantly the maximum torsion rigidity and blood vessel density in the subperiosteal region in rats at day 10 post fracture (Hrdna et al. 2015). From this perspective, local $\mathrm{MnCl}_{2}$ is a pharmaceutical with a potential to support fracture healing.

Like zinc, manganese accelerates growth (at least partly) via activation of somatomedin synthesis (reviewed by Zofkova et al. 2013). In oophorectomized rats, those supplemented with manganese had slower bone loss than rats without supplementation (Rico et al. 2000). The amount of manganese in bones of rats decreased after oophorectomy and normalized during estradiol treatment (Rahnama et al. 2003). The direct bone-protective effect of estrogen on bone metabolism is, therefore, intensified by manganese deposition.

Using an absorption spectrophotometric method, we found a positive association between serum manganese levels and bone mineral density, and a negative correlation between serum manganese and the number of fractures in a group of 40 post-menopausal women (Nemcikova et al. 2009). These results might suggest that manganese has some protective effect on bone health in hypoestrogenic women. These results were obtained in a small sample size, however, and should be confirmed by further investigations.

Nevertheless, manganese can also be toxic to humans. With its half-life of about 8-9 years, manganese accumulates substantially in bones. Long-term overexposure to manganese, with subsequent increase in manganese blood levels, may lead to dopaminergic dysfunction, which manifests as Parkinson's disease (O’Neal and Zheng 2015, Sánchez-González et al. 2015).

Finally, in physiological concentrations, manganese has a significant bone protective effect. The monitoring of manganese homeostasis is recommended in patients with a high risk of osteoporosis, although the toxic effect of supraphysiological concentrations should not be underestimated. The recommended daily intake of manganese is $1.8-2.3 \mathrm{mg}$ (Devrian and Volpe 2003).

\section{Selenium}

Selenium is an essential nutrient necessary for human and animal health due to a strong antioxidant action, which protects cells (including those in the skeleton) from oxidative damage. It is known that selenium deficiency activates bone resorption. Detrimental effects on bone microarchitecture were documented in mice (Cao et al. 2012) and on bone mineral density and growth in rats (Moreno-Reyes et al. 2001). In healthy humans, selenium status was negatively correlated with bone metabolic turnover and positively 
with bone density (Hoeg et al. 2012, reviewed by Zeng et al. 2013). A large study in a group of 2,374 euthyroid post-menopausal women showed that selenium levels positively correlated with hip and/or lumbar spine BMD and negatively with bone remodelling (Hoeg et al. 2012). Moreover, disabled elderly patients had low selenium and zinc levels, together with impaired total antioxidant score and low BMD (Younesi et al. 2015).

As mentioned above, skeletal effect of selenium is explainable by its antioxidative mechanism. In low antioxidative status, osteoclasts produce high amount of ROS, which is accompanied by activated bone resorption. Selenium substitution restores antioxidant capacity in bone cells and inhibits NF- $\mathrm{NB}$ - RANKL axis and osteoclast differentiation. In high doses, selenium induces apoptosis of mature osteoclasts. In addition, selenium strengthens osteoblast antioxidative defense. Through these mechanisms, selenium modulates bone metabolic turnover in favor of bone formation (reviewed by Zeng et al. 2013).

In summary, selenium appears to be a potent antioxidant element with a protective effect on the skeleton by maintaining cell redox balance. Nevertheless, a study by Arikan et al. (2011) failed to confirm any correlation between serum selenium and bone mass. A further, large investigation is, therefore, necessary to confirm possible use of selenoproteins in treatment of osteoporosis. The recommended daily dose of selenium is $55 \mu \mathrm{g} /$ day. An alarming fact is that in Europe, Africa and Asia the usual selenium intake is only around $25 \mu \mathrm{g} /$ day (Price et al. 2012).

\section{Zinc}

Zinc is known to regulate growth, neuronal development and immunity (Plum et al. 2010). Zinc positively influences the strength, flexibility and architecture of the skeleton in animals. The bone anabolic effect of the element was documented by an increase in osteocalcin and COL1A1 expression and serum alkaline phosphatase activity. Recently, zinc has also been shown to have beneficial effect on biomechanical bone parameters in rats (Bortolin et al. 2015). Osteoporotic post-menopausal women had significantly lower serum zinc levels than healthy controls (Midhavi-Roshan et al. 2015). Similarly, disabled elderly patients had significantly lower circulating zinc together with an impaired antioxidant score and lower bone mineral density, as compared to age-gender-matched controls (Younesi et al. 2015).
The bone protective effect of zinc is complex. The element is a growth-stimulator through activation of enzymes, which, support synthesis of DNA, RNA and proteins. Zinc increases osteoblastic activity and promotes synthesis of collagen. On the other hand, zinc inhibits osteoclastic bone resorption and thus disconnects bone remodelling in favor of bone formation (Lowe et al. 2002, reviewed by Zofkova et al. 2013). A study in adolescent rats suggested that severe zinc deficiency could have negative implications for future bone health (Ryz et al. 2009).

In addition, in zinc deficient rats serum PTH levels increased as a consequence of inhibition of calcium absorption in the intestine (Suzuki et al. 2015). Furthermore, zinc stabilizes the membrane of mast cells. Atik et al. (2006), on the basis of in vitro studies and observation in patients with senile osteoporosis, outlined the hypothesis on the role of hyperparathyroidism evoked by zinc deficiency, degranulation of mast cells, heparin release and increase in activity of prostaglandin $E_{2}$. Heparin, together with prostaglandin $E_{2}$, are the cofactors of parathormone, which intensifies the direct effect of zinc deficiency on bone resorption.

The favorable effect of zinc intake on bone remodelling, bone matrix formation and mineralization was demonstrated in growing rats (Headley et al. 2010). A study in humans showed positive correlation between serum zinc and osteocalcin and negative correlation between zinc and bone resorption markers (Hill et al. 2005). Similarly, zinc supplementation increased bone formation in premenarcheal girls (Berger et al. 2015).

Zinc has a beneficial effect on bone integrity throughout life. Newborn animals that were exposed to zinc deficiency had reduced production of somatomedin (IGF-I), the parameter important for initiating a growth spurt. However, decline in somatomedin synthesis also deteriorates bones in elderly people and contributes to the development of osteopenia and alteration of bone microarchitecture (reviewed by Zofkova et al. 2013). Therefore, zinc supplementation appears to have an important role in treatment and prevention of senile osteoporosis.

Zinc also protects the skeleton of alcoholics, which comes mainly from activation of anabolic processes in bone (Yamauchi et al. 2006). The administration of zinc to rats that were exposed to alcohol increased bone formation and the volume of trabecular bone (Gonzalez-Reimers et al. 2005). Zinc also reduces negative effects of toxic elements, such as lead or 
cadmium on osteoblasts (Jamieson et al. 2006, Brzóska et al. 2007).

The human body contains $2-3 \mathrm{~g}$ of zinc, and its average daily loss (approx. $0.1 \%$ ) would be normally covered by dietary intake. However, this is not always the case, and approximately $25 \%$ of the world's population is at risk of zinc deficiency, especially adolescents and postmenopausal women (Meunier et al. 2005). Zinc deficiency was associated with greater impairment in bone development than proteincaloric restriction, and it limited bone recovery during repletion in growing rats (Hosea et al. 2004). While the recommended daily minimum intake of zinc is $12 \mathrm{mg}, 15 \mathrm{mg}$ is necessary to increase bone density (Maret and Sanstead 2006). However, it should be noted that long-term administration of very high doses of zinc, particularly if the patient also has an existing copper deficiency, can lead to chronic zinc toxicity (Palacios 2006). Considering the above, zinc in physiological concentrations has an important bone-protective effect. Its deficiency leads not only to deterioration of growth, but also alters integrity of adult skeletons in humans and animals.

\section{Trace elements extremely detrimental to the skeleton}

\section{Cadmium}

Cadmium is soft, extremely toxic element found in high concentrations in industrial areas. It is mostly a by-product of mining and metal processing. The progress of industrialization leads to an increased risk of cadmium pollution as cadmium cannot be destroyed in nature. In high concentrations, cadmium induces oxidative stress, which causes aberrant DNA methylation, alters cell proliferation and differentiation, inhibits DNA damage repair and destabilizes the genome (Bishak et al. 2015). In other words, cadmium is a strong carcinogenic element. Moreover, when administered for a long time via inhalation, the element leads to pulmonary fibrosis and renal disorder.

Cadmium also seriously damages bone mass and bone quality. Its toxic effect on the skeleton has been demonstrated in a correlation study in a group of 850 postmenopausal women, in whom the bone density value negatively correlated with cadmium concentration in urine (Akeson et al. 2006). Engström et al. (2012) studied a group of nearly 3,000 postmenopausal women and found a negative association between cadmium intake and BMD at the total body and the lumbar spine, and a positive relationship with fracture risk, even when the cadmium exposure was relatively low. This is in consensus with the result of a small study, in which women with severe osteoporosis showed cadmium concentration in plasma significantly higher than control women (Sadeghi et al. 2014). Positive association between urinary calcium and cadmium content in kidney specimens obtained from biopsy and negative correlation between kidney cadmium and bone mineral density in women were observed by Wallin et al. (2013).

Cadmium has a negative impact on growth. Exposure to the element during pregnancy negatively influences birth size in neonates. In Bangladeshi women, maternal urinary cadmium inversely correlated with neonatal birth weight and head and chest circumferences in girls (Kippler et al. 2012). In 155 schoolchildren in Pakistan, two times higher cadmium concentration in urine was associated with 1.72 times increase in deoxypyridin and a 1.21 times increase in calcium excretion. This association, however, needs to be analyzed in other ethnic groups, too.

The mechanism of detrimental cadmium effect on the skeleton is not fully understood. In vitro study showed that longer exposure of human osteoblast-like cells to cadmium induced cytoskeleton disruption and accelerated cell apoptosis (Papa et al. 2015). Liang et al. (2015) found an elevated urinary $\beta_{2}$-microglobulin, which is a serious indicator of tubular dysfunction, in women subjected to long-term exposure to cadmium in the most polluted areas. Furthermore, Kim et al. (2014) found low values of BMD in exposed females, together with high urinary $\beta_{2}$-microglobulin. The tubular dysfunction (probably as a consequence of activated fibroblast growth factor 23) appears to be the fundamental cause of calcium-phosphate imbalance in cadmium-exposed subjects (Kido et al. 2014).

However, while an inverse correlation between urinary cadmium and BMD was found in men exposed to high cadmium concentrations, only $5 \%$ of them showed evidence of renal tubular disorder with urine $\beta_{2}$-microglobulin exceeding the value of $300 \mu \mathrm{g} / \mathrm{g}$ creatinine (Nawrot et al. 2010). Thus, the latter study shows that cadmium's negative influence on the skeleton is independent of the tubular effect. In vivo, cadmium inhibits bone formation and stimulates bone resorption, even at moderate concentrations. In toxic concentrations, cadmium breaks down the collagen matrix and inhibits its mineralization (reviewed by Zofkova et al. 2013). The detrimental effect of cadmium on metabolism of 
beneficial trace elements such as zinc, iron, magnesium, selenium, copper, and manganese should be also taken into account.

\section{Heavy metals (lead and chromium)}

Lead accumulates in bones over a long time and damages osteoblastogenesis. Beier et al. (2015) demonstrated a detrimental effect of long-term exposure to lead on bone accrual and bone strength in juvenile male mice. Women with higher lead content in their skeleton had thinner cortices in distal tibias and lower volumetric BMD (Wong et al. 2015). Furthermore, the latter parameter in the same gender negatively correlated with urinary lead levels (Tsai et al. 2015).

Chromium has a potentially harmful effect on bone health via oxidative stress. The element reduced osteoblast-like cell survival and activity in vitro in several different concentrations and incubation times, and decreased OPG/RANKL ratio (mainly due to stimulation of osteoclasts forming) (Zijlstra et al. 2012, Andrews et al. 2011). An imbalance in bone remodelling that favors resorption may contribute to complications following total hip arthroplasty. Relatively limited data exist on the detrimental effect of lead and chromium on the skeleton, therefore further investigations are necessary.

\section{Conclusions}

Many trace elements (e.g. boron, iron, magnesium, and manganese) are beneficial for bone health; however some are toxic, such as cadmium, cobalt and lead. It is important to note, nevertheless, that excessive intake of certain beneficial elements (fluoride, iron, magnesium, zinc) can also have toxic effects. For example, high intake of fluoride damages bone integrity. The positive or negative effect of trace elements depends, to a degree, on the influence of external environments (nutrition) and internal factors (individual absorption and metabolism of these elements, genetic disposition, age and gender). Finally, the effect of trace elements depends not only on their quantity in the diet but also on their mutual interactions (Khandare et al. 2005).

\section{Perspectives in the topic research}

The protective effect of selected trace elements on the skeleton has been confirmed; however theoretical and practical issues of supplementation in terms of osteoporosis prevention and treatment are still unknown. Data on the effect of individual elements are limited, partly because these elements are usually taken in combinations. In addition, homeostasis of trace elements in the body is determined by diet, as well as age and gender (Sakai et al. 2000). Due to these inconsistencies, further studies are necessary to confirm the effect of different doses, concentrations and interactions of individual trace elements on bone health. From this perspective, absorption spectrophotometry remains a valuable tool in measuring trace elements concentrations in body fluids (blood and urine) and tissues and, therefore, it contributes to the prevention and treatment of osteoporosis.

\section{Conflict of Interest}

There is no conflict of interest.

\section{Acknowledgements}

This work was supported by the project (Ministry of Health, Czech Republic) for conceptual development research organization 00023761 (Institute of Endocrinology, Prague, Czech Republic).

\section{References}

AINA V, LUSVARDI G, ANNAZ B, GIBBON IR, IMRIE FE, MALAVASI G, MENABUE L, CARRATO G, MARTRA G: Magnesium - and stroncium-co-substituted hydroxyapatite: the effects of doped-ions on the structure and chemico-physical properties. J Mater Sci Mater Med 23: 2867-2979, 2012.

AKESSON A, BJELLERUP P, LUNDH T, LIDFELDT J, NERBRAND C, SAMSIOE G, SAMSIOE G, SKERFVING S, VAHTER M: Cadmium-induced effects on bone in a population-based study of women. Environ Health Perspect 114: 830-834, 2006.

ANDREWS RE, SHAH KM, WILKINSON JM, GARTLAND A: Effects of cobalt and chromium ions at clinically equivalent concentrations after metal-on-metal hip replacement on human osteoblasts and osteoclasts: implications for skeletal health. Bone 49: 717-723, 2011. 
ARIKAN DC, COSKUN A, OZER A, KILINC M, ATALAY F, ARIKAN T: Plasma selenium, zinc, copper and lipid levels in postmenopausal Turkish women and their relation with osteoporosis. Biol Trace Elem Res 144: 407-417, 2011.

ATIK OS, USLU MM, EKSIOGLU F, SATANA T: Etiology of senile osteoporosis. a hypothesis. Clin Orthopaed Related Res 443: 25-27, 2006.

BERGER PK, POLLOCK NK, LAING EM, CHERTIN V, BERNARD PJ, GRIDER A, SHAPSES SA, DING KH, ISALES CM, LEWIS RD: Zinc supplementation increases procollagen type 1 amino-terminal propeptide in premenarcheal girls: a randomized controlled trial. J Nutr 145: 2699-2704, 2015.

BIER EE, INZANA JA, SUDU TJ, SHU L, PUZAS JE, MONEY RA: Effects of combined exposition to lead and highfat diet on bone quality in juvenile mice. Environ Health Perspect 123: 935-943, 2015.

BISHAK YK, PAYAHOO L, OSATDRAHIMI A, NOURAZARIAN A: Mechanisms of cadmium carcinogenicity in the gastrointestinal act. Asian Pac J Cancer Prev 16: 9-21, 2015.

BORTOLIN RH, DA GRACA AVEZEDO AREU BJ, ABBOLTT CALVAO URURAHY M, COSTA DE SOUZA KS, BEZERRA JF, LOUREIRO MB, DA SILVA FS, MARQUES DE, BATISTA AA, OLIVEIRA G, ET AL.: Protection against T1DM-induced bone loss by zinc supplementation: biomechanical, histomorphometric, and molecular analyses in STZ-induced diabetic rats. PLoS One 10: e0125349, 2015.

BREWER GJ: Copper in medicine. Curr Opin Chem Biol 7: 207-212, 2003.

BRZÓSKA MM, ROGALSKA J, GALAZYN-SIDORCZUK M, JURCZUK M, ROSZCZENKO A, KULIKOWSKA-KARPIŃSKA E, MONIOSZKO-JAKONIUK J: Effect of zinc supplementation on bone metabolism in male rats chronically exposed to cadmium. Toxicology 237: 89-103, 2007.

CAO JJ, GREGOIRE BR, ZENG H: Selenium deficiency decreases antioxidative capacity and is detrimental to bone microarchitecture in mice. J Nutr 142: 1526-1531, 2012.

CASTIGLIONI S, CAZZANIGA A, ALBISETTI W, MAIER JA: Magnesium and osteoporosis: current state of knowledge and future research directions. Nutrients 5: 3022-3033, 2013.

CHACHRA D, LIMEBACK H, WILLETT TL, GRYNPAS MD: The long-term effects of water fluoridation on the human skeleton. J Dent Res 89: 1219-1223, 2010.

CHAYA A, YOSHIZAWA S, VERDELIS K, MYERS N, COSTELLO BJ, CHOU DT, PAL S, MAITI S, KUMTA PN, SFEIR C: In vivo study of magnesium plate and screw degeneration and bone fracture healing. Acta Biomater 18: 262-269, 2015.

COYLE L, ENTEZARALMAHDI M, ADEOLA M, DE HOYOS P, MEHED A, VARON J: The perfect storm: copper deficiency presenting as progressive peripheral neuropathy. Am J Emerg Med. 34: 340.e5-340.e6, 2016.

DEVIRIAN TA, VOLPE SL: The physiological effects of dietary boron. Crit Rev Food Sci Nutr 43: 219-231, 2003.

DIAZ-CASTRO J, LÓPEZ-FRIAS MR, CAMPOS MS, LÓPEZ-FRIAS M, ALFÉREZ MJ, NESTARES T, OJEDA ML, LÓPEZ-ALIAGA I: Severe nutritional iron-deficiency anaemia has a negative effect on some bone turnover biomarkers in rats. Eur J Nutr 51: 241-247, 2012.

DIAZ-CASTRO J, RAMÍREZ LÓPEZ-FRIAS M, CAMPOS MS, LÓPEZ-FRIAS M, ALFÉREZ MJ, NESTARES T, ORTEGA E, LÓPEZ-ALIAGA I: Goat milk during iron repletion improves bone turnover impaired by severe iron deficiency. J Diary Sci 94: 2752-2761, 2011.

ENGSTRÖM A, MICHAËLSSON K, VATER M, JULIN B, WOLK A, ÄKESSON A: Associations between dietary cadmium exposure and bone mineral density and risk of osteoporosis and fractures among women. Bone 50: 1372-1378, 2012.

FAYHOE RP, LENTJES MA, LUBEN RN, KHAW KT, WELCH A: Dietary magnesium and potassium intakes and circulating magnesium are associated with heel bone ultrasound attenuation and osteoporotic fracture risk in the EPIC-Norfolk cohort study. Am J Clin Nutr 102: 376-384, 2015.

GONZALEZ-REIMERS E, DURAN-CASTELLON M, MARTIN-OLIVERA R, POLEZ-RAMÍREZ A, GARCIAVALDECASAS COPMPELO E: Effects of zinc supplementation on ethanol-mediated bone alterations. Food Chem Toxicol 43: 1497-1505, 2005.

GREY A, GARG S, DRAY M, PURVIS L, HORNE A, CALLON K, GAMBLE G, BOLLAND M, REID IR, CUNDY T: Low-dose fluoride in postmenopausal women: a randomized controlled trial. J Clin Endocrinol Metab 98: 2301-2307, 2013. 
GUGGENBUHL P, DEUGNIER Y, BOISDET JF, ROLLAND Y, PERDRIGER A, PAWLOTSKY Y, CHALES G: Bone mineral density in men with genetic hemochromatosis and HFGE gene mutation. Osteoporosis Int 16: 1809-1814, 2005.

HAKKI SS, DUNDAR N, KAYIS SA, HAKKI EE, HAMURCU, KERIMOGLU U, BASPINAR N, BASOVOU A, NIELSEN FH: Boron enhances strength and alters mineral composition of bone in rabbits fed a high energy diet. J Trace Elem Med Biol 27: 148-153, 2013.

HEADLEY KB, NEWMAN SM, HUNT JR: Dietary zinc reduces osteoclast resorption activities and increases markers of osteoblast differentiation, matrix maturation, and mineralization in the long bones of growing rats. $J$ Nutr Biochem 21: 297-303, 2010.

HILL T, MEUNIER N, ANDRIOLLO-SANCHEZ M, CIARAPICA D, HININGER-FAVIER I, POLITO A, O'CONNOR JM, COUDRAY C, CASHMAN KF: The relationship between the zinc nutritive status and biochemical markers of bone turnover in older European adults: the ZENITH study. Eur J Clin Nutr 59 (Suppl 2): S73-S78, 2005.

HOEG A, GOGAKOS A, MURENY E, MUELlER S, KÖHRLE J, REID DM, GLÜER CC, FELSENBERG D, ROUX C, EASTELL R, SCHONBURG L, WILLIAMS GR: Bone turnover and bone mineral density are independently related to selenium status in healthy euthyroid postmenopausal women. Clin Endocrinol Metab 97: 4061-4070, 2012.

HORDYJEWSKA A, POPIOLEK L, KOCOT J: The many „faces“ of copper in medicine and treatment. Biometals 27: 611-621, 2014.

HOSEA HJ, TAYLOR CG, WOOD T, MOLLARD R, WEILER HA: Zinc-deficient rats have more limited bone recovery during repletion than diet-restricted rats. Exp Biol Med (Maywood) 229: 303-311, 2004.

HREHA J, WEY A, CUNNINGHAM C, KRELL ES, BRIETBART EA, PAGLIA DN, MONTEMURRO NJ, NGUYEN DA, LEE YJ, KOMLOS D, ET AL.: Local manganese chloride treatment accelerates fracture healing in a rat model. J Orthop Res 33: 122-130, 2015.

HUNT CD: Dietary boron: progress in establishing essentials roles in human physiology. J Trace Elem Med Biol 26: 2-3, 2012.

JAMIESON JA, TAILOR CG, WEILER HA: Marginal zinc deficiency exacerbates bone lead accumulation and high dietary zinc attenuates lead accumulation at the expense of bone density in growing rats. Toxicol Sci 2006: 286-249, 2006.

JHA SK, MISHRA VK, SHARMA DK, DAMODARAN T: Fluoride in the environment and its humans. Rev Environ Contam Toxicol 211: 121-142, 2011.

KHANDARE AL, SURESH P, KUMAR PU, LAKSMAIAH N, MANULA N, RAO G: Beneficial effect of copper supplementation on deposition of fluoride in bone in fluoride - and molybdenum-fed rabbits. Calcif Tissue Int 77: 233-238, 2005.

KIDO S, FUJIHARA M, NOMUR K, SASAKI S, MUKAI R, OHNISHI R, KANEKO I, SEGAWA H, TATSUMI S, IZUMI H, KOHNO K, MIYAMOTO K: Molecular mechanisms of cadmium-induced fibroblast growth factor 23 upregulation in osteoblast-like cells. Toxicol Sci 139: 301-316, 2014.

KIM YD, YIM DH, EOM SY, MOON SI, PARK CH, KIM GB, YU SD, CHOI BS, PARK JD, KIM H: Differences in the susceptibility to cadmium-induced renal tubular damage and osteoporosis according to sex. Environ Toxicol Pharmacol 38: 272-278, 2014.

KIPPLER M, TOFAIL F, GARDNER R, RAHMAN A, HAMADANI JD, BOTTAI M, VAHTER M: Maternal cadmium exposure during pregnancy and size at birth: a prospective cohort study. Environ Health Perspect 120: $284-289,2012$.

KOROGLU BK, ERSOY IH, KOROGLU M, BAKALI A, ERSOY S, VAROL S, TAMER MN: Serum parathyroid hormone levels in chronic endemic fluorosis. Biol Trace Elem Res 143: 79-86, 2011.

KUBIAK K, KLIMCZAK A, DZIKI L, MODRANKA R, MALINOWSKA K: Influence of copper (II) complex on the activity of selected oxidative enzymes. (In Polish) Pol Merkur Lekarski 28: 22-25, 2010.

KUMAR N, GROSS JB JR, AHLSKOG JE: Copper deficiency myelopathy produces a clinical picture like subacute combined degeneration. Neurology 63: 33-39, 2004. 
LI BB, YU SF: In vitro study of the effects of copper ion on osteoclastic resorption in various dental mineralized tissues. Zhoghua Kou Qiang Yi Xue Za Zhi 42: 110-113, 2007.

LEIDI M, DELLERA F, MARIOTTI M, MAIER JA: High magnesium inhibits human osteoblast differentiation in vitro. Magnes Res 24: 1-6, 2011.

LEVY SM, WARREN JJ, PHIPPS K, LETUCHY E, BROFFITT B, EICHENBERGER-GILMORE J, BURNS TL, KAVAND G, JANZ KF, TORNER JC, PAULEY CA: Effects of life-long fluoride intake on bone measures of adolescents: a prospective cohort study. J Dent Res 93: 353-359, 2014.

LIANG Y, LEI L, NILSSON J, LI H, NORDBERG M, BERNARD A, NORDBERG GF, BERGDAHL IA, JIN T: Renal function after reduction in cadmium exposure: an 8-year follow - up of residents in cadmium-polluted areas. Environ Health Perspect 120: 223-228, 2015.

LIU R, JIN C, WANG Z, WANG Z, WANG J, WANG L: Effects of manganese deficiency on the microstructure of proximal tiba and OPG/RANKL gene expression in chicks. Vet Res Commun 39: 31-37, 2015.

LOWE NM, FRASER WD, JACKSON MJ: Micronutrient group symposium on micronutrient supplementation: is there a case? Is there a potential therapeutic value of copper and zinc for osteoporosis? Proc Nutr Soc 61: 181-185, 2005.

MADEIROS DM, STOECKER B, PLATTNER A, JENNINGS D, HAUB M: Iron deficiency negatively affects vertebrae and femurs of rats independently of energy intake and body weight. $J$ Nutr 34: 3061-3067, 2004.

MARET W, SANDSTEAD HH: Zinc requirements and the risks and benefits of zinc supplementation. $J$ Trace Elem Med Biol 20: 3-18, 2006.

MARQUARDT ML, DONE SL, SANDROCK M, BERDON WE, FELDMAN KW: Copper deficiency presenting as metabolic bone disease in extremely low birth weight, short-gut infants. Pediatrics 130: e695-e698, 2012.

MEUNIER N, O'CONNOR JM, MAIANI G, CASHMAN KD, SECKER DL, FERRY M, ROUSSEL AM, COUDRAY C: Importance of zinc in the elderly: the ZENITH study. Eur J Clin Nutr 59 (Suppl 2): S1-S4, 2005.

MEYER TE, VERWOERT GC, HWANG SJ, GLAZER NL, SMITH AV, VAN ROOIJ FJ, EHRET GB, BOERWINKLE E, FELIX JF, LEAK TS, ET AL.: Genome-wide association studies of serum magnesium, potassium, and sodium concentrations identify six loci influencing serum magnesium levels. PLoS Genet $\mathbf{6}$ : e1001045, 2010.

MIDHAVI-ROSHAN M, EBRAHIMI M, EBRAHIMI A: Cooper, magnesium, zinc and calcium status in osteopenic and osteoporotic post-menopausal women. Clin Cases Miner Bone Metab 12: 18-21, 2015.

MORENO-REYES R, EGRISE D, NÈVE J, PASTEELS JL, SCHOUTENS A: Selenium deficiency-induced growth retardation is associated with an impaired bone metabolism and osteopenia. J Bone Miner Res 16: 1556-1563, 2001.

NAWROT T, GEUSENS P, NULENS TS, NEMERY B: Occupational cadmium exposure and calcium excretion, bone density, and osteoporosis in men. $J$ Bone Miner Res 25: 1441-1445, 2010.

NEMCIKOVA P, SPEVACKOVA V, CEJCHANOVA M, HILL M, ZOFKOVA I: Relationship of serum manganese and copper levels to bone density and quality in postmenopausal women. A pilot study. Osteol Bull 14: 97-100, 2009.

NIELSEN FH, STOECKER B: Boron and fish oil have different beneficial effects on strength and trabecular microarchitecture of bone. J Trace Elem Med Biol 23: 195-203, 2009.

NIEVES JW: Skeletal effects of nutrients and nutraceuticals, beyond calcium and vitamin D. Osteoporos Int 24: 771-786, 2009.

OHNO M, KIMOTO K, TOYODA T, KAWATA K, ARAKAWA H: Fluoride-treated bio-resorbable synthetic nonceramic (corrected) hydroxyapatite promotes proliferation and differentiation of human osteoblastic MG-63 cells. J Oral Implantol 39: 154-160, 2013.

O'NEAL SL, ZHENG W: Manganese toxicity upon overexposure: a decade in review. Curr Environ Health Rep 2: 315-328, 2015.

PAGE PS, NAZAR RG, PARK MC, JAMES RF: Copper deficiency myelopathy in the setting of advanced degenerative cervical spondylosis. Br J Neurosurg. 30: 453-455, 2016.

PALACIOS C: The role of nutrients in bone health, from A to Z. Crit Rev Food Sci Nutr 46: 621-628, 2006. 
PAN L, SHI X, LIU S, GUO X, ZHAO M, CAI R, SUN G: Fluoride promotes osteoblastic differentiation through canonical Wnt/ $\beta$-catenin signaling pathway. Toxicol Lett 225: 34-42, 2014.

PAPA V, BIMONTE VM, WANNENES F, D’ABUSCO AS, FITTIPALDI S, SCANDURRA R, POLITI L, CRESCIOLI C, LENZI A, Di LUIGI L, MIGLIACCIO S: The endocrine disruptor cadmium alter human osteoblast-like Saos-2 cells homeostasis in vitro by alteration of Wnt/ $\beta$-catenin pathway and activation of caspases. J Endocrinol Invest 38: 1345-1356. 2015.

PARELMAN M, STOECKER B, BAKER A, MEDEIROS D: Iron restriction negatively affects bone in female rats and mineralization of hFOB osteoblast cells. Exp Biol Med (Maywood) 231: 378-386, 2006.

PLUM LM, RINK L, HAASE H: The essential toxin: impact of zinc on human health. Int J Environ Res Public Health 7: 1342-1365, 2010.

PRICE CT, LANGFORDT JR, LIPORACE FA: Essential nutrients for bone health and a review of their availability in the average north american diet. Open Orthop J 6: 143-149, 2012.

PURANIK CP, RYAN KA, YIN Z, MARTINEZ-MIER EA, PREISSER JS, EVERETT ET: Fluoride modulates parathyroid hormone secretion in vivo and in vitro. Cells Tissues Organs 200: 413-423, 2015.

RAHNAMA M, BLONIARZ J, ZAREBA S, SWIATKOWSKI W: Study of estrogen deficiency impact on manganese levels in teeth and mandible of rats after ovariectomy. Rocz Panstw Zakl Hig 54: 33-38, 2003.

RICO H, GÓMEZ-RASO N, SEVILLA M, HERNÁNDFEZ ER, SECO C, PÁEZ E, CRESPO E: Effects on bone loss of manganese alone or with copper supplement in ovariectomized rats. a morphometric and densitometric study. Eur J Obstet Gynecol Reprod Biol 90: 97-101, 2000.

RUDE RK, SINGER FR, GRUBER HE: Skeletal and hormonal effects of magnesium deficiency. J Am Coll Nutr 28: 131-141, 2009.

RUNNELS LW: TRPM6 and TRPM7: a Mul-TRP-PLIK-cation of channel functions. Curr Pharm Biotechnol 12: 42-53, 2011.

RYZ NR, WEILER HA, TAILOR CG: Zinc deficiency reduces bone mineral density in the spine of young adult rats: a pilot study. Ann Nutr Metab 54: 218-26, 2009.

SADEGHI N, OVEISI MR, NAHNAT B, HAJIMAHMOODI M, BEHZAD M, BEHFAR A, SADEGHI F, SAADATMAND S: The relationship between bone health and plasma zinc, copper, lead and cadmium concentration in osteoporotic women. J Environ Health Sci Eng 12: 125, 2014.

SAKAI T, WARIISHI M, NISHIYAMA K: Changes in trace element concentrations in hair of growing children. Biol Trace Elem Res 77: 43-51, 2000.

SÁNCHEZ-GONZÁLEZ C, LÓPEZ-CHAVES C, GÓMEZ-ARACENA J, GALINDO P, ARANDA P, LLOPIS J: Association of plasma manganese levels with chronic renal failure. J Trace Elem Med Biol 31: 78-84, 2015.

SIERPINSKA T, KONSTANTYNOWICZ J, ORYWAL K, GOLEBIEWSKA M, SZMITKOWSKI M: Copper deficit as a potential pathogenic factor of reduced bone mineral density and severe tooth wear. Osteoporos Int $\mathbf{2 5}$ : 447-454, 2014.

SONG YE, TAN H, LIU KJ, ZHANG YZ, LIU Y, LU DL, TU J, CUI CY: Effect of fluoride exposure on bone metabolism indicators ALP, BALP, and BGP. Environ Health Prev Med 16: 158-163, 2011.

SUZUKI T, KAJITA Y, KATSUMATA S, MATSUZAKI H, SUZUKI K: Zinc deficiency increases serum concentration of parathyroid hormone through a decrease in serum calcium and induces bone fragility in rats. J Nutr Sci Vitaminol (Tokyo) 5: 382-390, 2015.

TSAI TL, PAN WH, CHUNG YT, WU TN, TSENG YC, LIOU SH, WANG SL: Association between urinary lead and bone health in a general population from Taiwan. J Expo Sci Environ Epidemiol 26: 481-487, 2016.

TURNER CH, GARETTO LP, DUNIPACE AJ, ZHANG W, WILSON ME, GRYNPAS MD, CHACHRA D, MCCLINTOCK R, PEACOCK M, STOOKEY GK: Fluoride treatment increased serum IGF-1, bone turnover, and bone mass, but not bone strength, in rabbits. Calcif Tissue Int 61: 77-83, 1997.

VAN LAECKE S, VAN BIESEN W: Hypomagnesaemia in kidney transplantation. Transplant Rev (Orlando) 29: 154-160, 2015.

VOLPE SL: Magnesium in disease prevention and overall health. Adv Nutr 4: 378S-383S, 2013. 
WALLIN M, SALLSTEN G, FABRICIUS-LAGGING, E, OHRN C, LUNDH T, BARREGARD L: Kidney cadmium levels and association with urinary and bone mineral density: a cross-sectional study in Sweden. Environ Health 12: 22, 2013.

WONG AK, BEATTIE KA, BHARGAVA A, CHEUNG M, WEBBER CE, CHETTLE DR, PAPAIOANNOU A, ADACHI JD, CANADIAN MULTICENTRE OSTEOPOROSIS STUDY (CaMOS) RESEARCH GROUP: Bone lead $(\mathrm{Pb})$ content at the tibia is associated with thinner distal tibia cortices and lower volumetric bone density in postmenopausal women. Bone 79: 58-64, 2015.

WRIGHT I, BLANCO-ROJO R, FERNÁNDEZ MC, TOXQUI L, MORENO G, PÉREZ-GRANADOS AM, DE LA PIEDRA C, REMACHA ÁF, VAQUERO MP: Bone remodelling is reduced by recovery from iron deficiency anaemia in premenopausal women. J Physiol Biochem 69: 889-896, 2013.

XIAO W, BIEBEI D, GUANGSI X, YU J, WEN Z, XI H, YOUJIA X: Iron overload increased osteoclastogenesis and aggravates the effects of ovariectomy on bone mass. J Endocrinol 226: 121-134, 2015.

YAMAGUCHI M, UCHIYAMA S, HASHIMOTO K: Oral administration in combination with zinc enhances $\beta$-cryptoxanthin-induced anabolic effects on bone components in the femoral tissues of rats in vivo. Biol Pharm Bull 29: 371-374, 2006.

YOSHIZAWA S, BROWN A, BRCHOWSKY A, SFEIR C: Magnesium ion stimulation of bone marrow stromal cells enhances osteogenic activity, stimulating the effect of magnesium alloy degradation. Acta Biomater 10: 2834-2342, 2014.

YOUNESI S, PARSIAN H, HOSSEINI SR, NOREDDINI H, MOSAPOUR A, BIJANI A, HALALKHOR S: Dyshomeostasis of serum oxidant/antioxidant status and copper, zinc, and selenium levels in elderly physically disabled persons: an AHAP-based study. Biol Trace Elem Res 166: 136-141, 2015.

ZENG H, CAO JJ, COMBS GF JR: Selenium in bone health: roles in antioxidant protection and cell proliferation. Nutrients 5: 97-110, 2013.

ZIJLSTRA WP, BULSTRA SK, VAN RAAY JJ, VAN LEEUVEN BM, KUIJER R: Cobalt and chromium ions reduce human oseoblast-like cell activity in vitro, reduce the OPG to RANKL ratio, and induce oxidative stress. J Orthop Res 30: 740-747, 2012.

ZOFKOVA I, NEMCIKOVA P, MATUCHA P: Trace elements and bone health. Clin Chem Lab Med 51: 1555-1561, 2013. 